\title{
Foreign Press and Academic Libraries
}

\begin{abstract}
In an effort to determine the extent to which American college students may gauge current trends in foreign thought, a questionnaire was sent to 350 academic libraries requesting them to check their holdings of foreign news serials.

The results indicate that academic libraries appear to give greatest news serial coverage to world powers and pro-western nations in their serial acquisitions, and that it is doubtless difficult for most college students to find a balance in the coverage of international events.
\end{abstract}

$\mathrm{T}$ HE LAST HALF CENTURY has seen the United States forced, politically and economically, to abandon its isolationism in world affairs. A large share of the problems of rebuilding Europe, of formulating a China policy, of preserving Korea and Vietnam, as well as of preventing nuclear disaster and total war has been thrust upon a people who had spent the greatest part of their history believing the best foreign policy was one of nonentangling alliances. With William McKinley went an era in which the American minded his own business.

A democracy which deals effectively in world affairs needs a mature population which can understand foreign affairs with tolerance and understanding. Whether it be in Saigon, Berlin, or Tel Aviv, our foreign policy can rise only as high as the American peope will let it rise.

Sociologists have concluded that it is best to understand the actions of a group in the light of their own culture and traditions. The best way to judge the actions of foreign nations is likewise in terms of their predominant cultural thought and activities. Is it possible for

Miss Wall is reference and circulation librarian in Shippensburg State College, Pennsylvania. the American citizen to locate sources which reveal the current trends in foreign thought and the reaction of foreigners to the day-to-day events of our time? Is it the responsibility of college and university libraries to provide this information?

A foreigner visiting the United States wishing to become acquainted with the most recent trends in American public opinion could find it reflected in the country's daily press and "slick" magazines. But can American students find similar information on foreign countries in their college and university libraries? The present study seeks to answer this question.

A questionnaire was mailed to three hundred and fifty college and university libraries which were selected from the American Library Directory. The sample comprised every third library in the United States with a total budget of over $\$ 25,000$. The questionnaire contained a list of foreign news serials which librarians were asked to check against their holdings.

The list of serials was selected from those cited in Atlas, a monthly news and literary magazine which translates editorials, short features, and news articles from foreign serials. In formulating the list, seventeen issues of Atlas were examined, or every third issue from 1961 
to 1965. All serial titles mentioned two or more times in separate articles were placed on the list.

Of the three hundred and fifty questionnaires sent, two hundred and fiftyeight, or 73.71 per cent, were filled out and returned. Table 1 shows the total list of titles and the number of libraries which hold each title.

TABLE 1

\begin{tabular}{cc}
\hline & $\begin{array}{c}\text { No. of } \\
\text { Libraries } \\
\text { Receiving }\end{array}$ \\
\hline
\end{tabular}

Al Ahram (Egypt)

Al Akhbar (Lebanon)

Al Gomhouria (Egypt)

Anhembi (Brazil)

Arts (France)

The Asia Magazine (Hong Kong)

Carrefour (France)

Christ and Welt

(West Germany)

Corriere Della Serra (Italy)

Dagens Nyheter (Sweden)

Daily Express (England)

Daily Mail (England)

Daily Mirror (Australia)

Daily Telegraph (England)

Deutsche Zeitung (West Germany)

Diaro De Noticias (Brazil)

Drum (Ghana)

Eastern World (England)

The Economist (England)

Eleutheria (Greece)

Epoca (Italy)

Estado De Sao Paulo (Brazil)

L'Express (France)

L'Expresso (Italy)

Far Eastern Economic Review (Hong Kong)

Le Figaro (France)

Le Figaro Littéraire (France)

Forum (Republic of South Africa)

Forum Service (England)

France Observateur (France)

Frankfurter Allgemeine Zeitung

(West Germany)

Hindu Weekly Review (India)

International Affairs (Russia)

Izvestia (Russia)

The Jerusalem Post (Israel)
Jeune Afrique (Tunis)

Journal Do Brasil (Brazil)

Kurier (Austria)

Link (India)

Literaturnaya Gazete (Russia)

London Observer (England)

London Times (England)

Ludas Matyi (Hungary)

Mainichi Shimbum (Japan)

Manchester Guardian Weekly (England)

Manchete (Brazil)

Le Monde (France)

Le Monde Diplomatique (1

Il Mondo (Italy)

La Nacion (Brazil)

Nepszabadsag (Hungary)

Neue Zürcher Zeitung (Switzerland)

Neues Deutschland (East Germany)

Les Nouvelles Littéraires (France)

New Commonwealth (England)

Novy Mir (Russia)

L'Osservatore Politico Letterario (Italy)

New Statesman (England)

Palante (Cuba)

Paris Match (France)

Peking Review (China)

Philippines Free Press

Pictures of Greece (Greece)

Polish Perspective (Poland)

Polityka (Czechoslovakia)

Pravda (Russia)

Preuves (France)

Quadrant (Australia)

The Queen (England)

Quest (India)

Renmin Ribao (China)

The Reporter (Kenya)

Review of International Affairs (Yugoslavia)

Spectator (England)

Der Spiegel (West Germany)

La Stampa (Italy)

Statesman; Week-End Review (India)

Statist (England)

Stern (West Germany)

Suddeutsche Zeitung

(West Germany)

Sunday Telegraph (England)

The Sunday Times (England)
187 
Survey (England)

Swiss Review of World Affairs

(Switzerland)

The Tablet (England)

V. D. I. Nachrichten

(West Germany)

The Weekly News (New Zealand)

Die Welt (West Germany)

Die Weltwoehe (Switzerland)

West African (England)

West African Pilot (Nigeria)

Die Zeit (West Germany)

Zeri I Popullit (Albania)
41

46

31

2

1
38

7

4

5

73

1
As would be expected, the libraries with smaller budgets have fewer of these publications. Table 2 indicates the number of titles held for five different sizes of libraries.

The average holding per library was 8.4 titles. For the libraries with budgets under $\$ 100,000$, foreign news coverage is very limited and in some cases non-
TABLE 2

\begin{tabular}{c|l|c}
\hline \hline $\begin{array}{c}\text { Number of } \\
\text { libraries }\end{array}$ & \multicolumn{1}{|c|}{$\begin{array}{c}\text { Budget range } \\
\text { (in dollars) }\end{array}$} & $\begin{array}{c}\text { Average } \\
\text { number of } \\
\text { titles held }\end{array}$ \\
\cline { 3 - 4 } 34 & $0-49,999$ & 3.2 \\
78 & $50,000-99,999$ & 5.2 \\
78 & $100,000-499,999$ & 8.6 \\
14 & $500,000-999,999$ & 19.3 \\
15 & $1,000,000-$ & 30.0 \\
\hline
\end{tabular}

existant. Eleven libraries hold none of the titles listed.

Representation by areas and countries show that libraries tend to represent major world powers, and generally proWestern powers, at the expense of neutrals and lesser Communist nations. The holding of one hundred copies of Polish Perspective is an obvious exception to this generalization.

Table 3 is a numerical comparison of the countries' representation on the original list with their appearance in Ameri-

TABLE 3

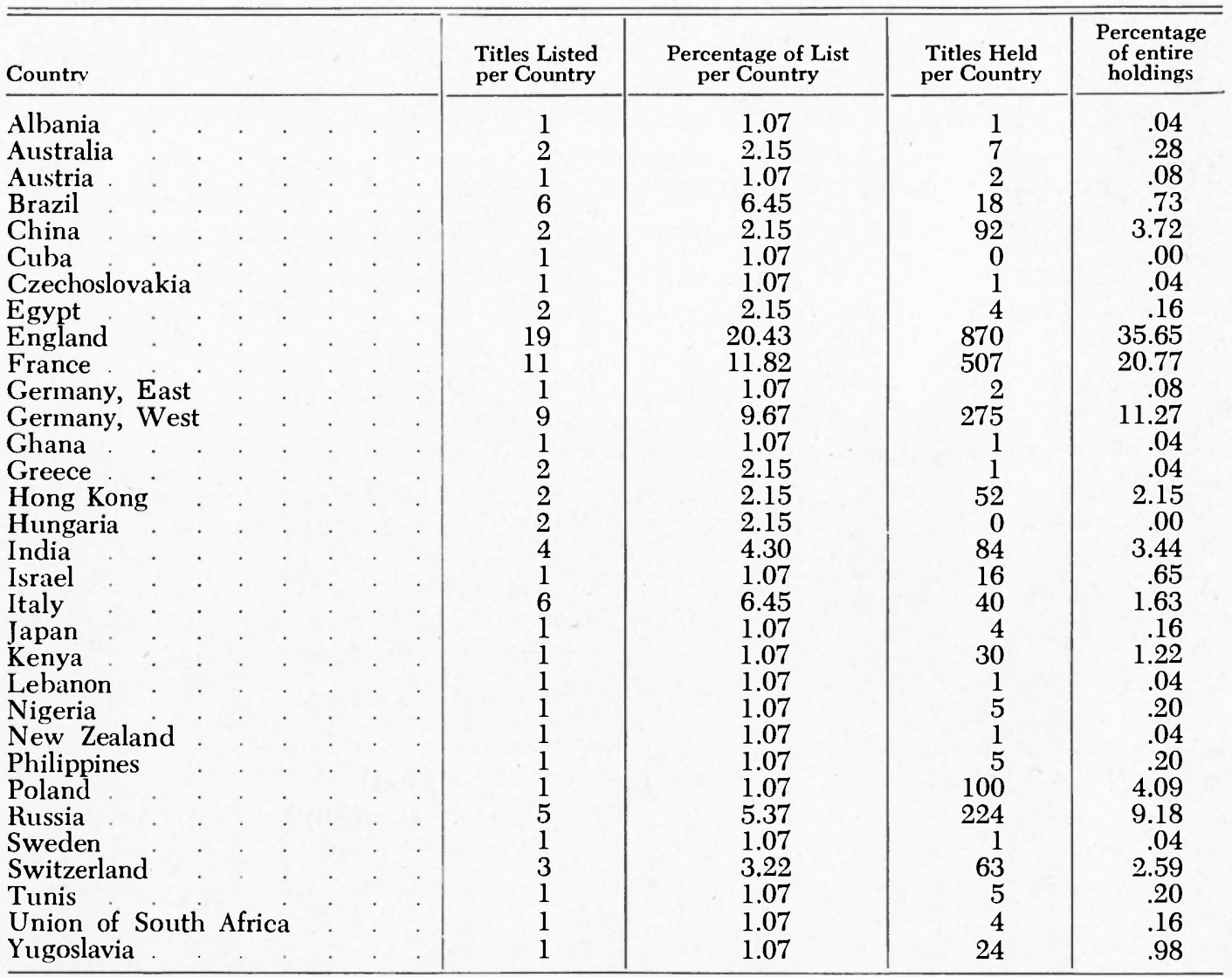


TABLE 4

\begin{tabular}{|c|c|c|}
\hline Language & $\begin{array}{l}\text { Number of } \\
\text { Titles Listed }\end{array}$ & $\begin{array}{l}\text { Number of } \\
\text { Titles Held }\end{array}$ \\
\hline English & 41 & 1381 \\
\hline German & 13 & 296 \\
\hline French & 12 & 512 \\
\hline Italian & 6 & 40 \\
\hline Portugese & 6 & 18 \\
\hline Russian & 4 & 177 \\
\hline Arabic . & 3 & 5 \\
\hline Hungarian & 2 & 0 \\
\hline Albanian . & 1 & 1 \\
\hline Chinese & 1 & 7 \\
\hline Czechosolovakian & $\hat{1}$ & i \\
\hline Greek & 1 & 1 \\
\hline Spanish & 1 & 0 \\
\hline Swedish & 1 & 1 \\
\hline
\end{tabular}

can academic library current serial holdings.

The English and French titles alone make up almost two-thirds of the titles listed. Significantly, the number of times these titles are held makes up over 55 per cent of the total foreign serial holdings.

The "language barrier" is sometimes given as the reason for low holding in foreign news serials. The languages represented on the original list are shown as Table 4. (Titles are counted as English when there is an available English edition.)

Yet the colleges and universities represented in this study teach foreign languages as shown in Table 5.

Thus, although it may be a bit idealistic to reject the "language barrier" argument too readily, it should, at least in theory, not account fully for the lack of foreign serial holdings.

Any conclusions drawn from a survey
TABLE 5

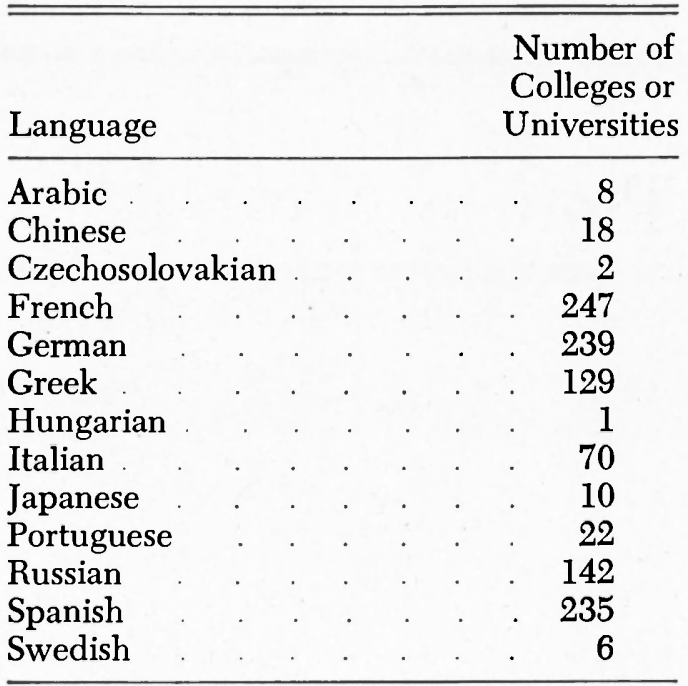

of this type are, of course, limited by the fact that an arbitrary list of serials was used. It would be difficult, however, to discredit its findings entirely on that basis.

One might conclude from this brief study that the American student finds it difficult to locate balanced daily foreign news coverage. It seems further that students are more likely to get foreign news coverage from countries such as Germany, France, England, and Russia, which are thought of as world powers. African countries, smaller Communist nations, as well as neutral countries receive little coverage. Since this does not appear to be due entirely to a language barrier, it is tempting to suspect that it might be attributed to a bias toward nations with power and prestige. 